\title{
Implikasi Pasal-Pasal Pelindung (The Trips Safeguards) Dalam UU Paten Indonesia: Kritik, Evaluasi Dan Saran Dari Perspektif Akses Terhadap Obat Yang Murah Dan Terjangkau
}

\author{
Oleh: Tomi Suryo Utomo \\ Dosen FH Universitas Janabadra Yoggyakarta \\ E mail: utomo_ts@yahoo.com
}

\begin{abstract}
The discussion about access to essential medicine issues nowadays cannot be separated from the TRIPS Agreement. The TRIPS Agreement is important because one of its provisions (Article 27) deals with the protection of pharmaceutical patent which has a great relevance to access to essential medicine issues, such as affordability of drugs. The TRIPS Agreement also regulates a series of policies called the TRIPS safeguards, such as parallel imports, bolar provision, compulsory license and government use that can minimize and manage the impact of pharmaceutical patent protection on access to essential medicines. Indonesia's patent law includes the safeguards provided by the TRIPS Agreement, such as parallel importation, bolar provisions, compulsory licenses and government use. However, several areas need to be improved so that the safeguards can be effectively used to manage the impact of pharmaceutical patent protection on access to medicines. Indonesia should seek a balance between pharmaceutical patent protection and use of policies and strategies that are essential for its public welfare.
\end{abstract}

Keywords: the Trips Safeguards, UU Paten, obat murah

\section{Pendahuluan}

Keberadaan pasal-pasal pelindung di dalam perjanjian TRIPS (the TRIPS Safreguards) membawa harapan kepada negara-negara berkembang dan terbelakang yang memang memiliki keterbatasan akses terhadap obat yang murah dan terjangkau. Para pengamat dan peneliti di bidang HaKI juga menyambut dengan antusias terhadap pasal pelindung tersebut. Mereka berpendapat bahwa pasal pelindung memang sudah seharusnya 
disisipkan di dalam perjanjian TRIPS sebagai balas jasa terhadap kerelaan negara-negera di dunia ketiga yang telah bersedia menandatangani dan tunduk dengan perjanjian TRIPS. Harapan ini bukanlah sesuatu yang berlebihan mengingat penundukan diri terhadap TRIPS membawa konsekuensi tersendiri kepada negara-negara tersebut.

Sebagai contoh, negara-negara berkembang dan terbelakang yang nota bene masih menjadi konsumen terhadap produk-produk sarat HaKI, harus menyesuaikan segala bentuk peraturan, pranata hukum serta sistim penegakan hukum agar memenuhi standard TRIPS. Konsekuensi lainnya yang harus dihadapi adalah berupa dampak-dampak negatif yang timbul selama masa penyesuaian terhadap perjanjian TRIPS diantaranya harga obat yang semakin mahal. Dengan diaturnya pasal-pasal pelindung tersebut, diharapkan dampak yang tidak diinginkan tersebut dapat diminimalkan.

Seiring dengan semakin banyaknya penduduk miskin di negara dunia ketiga yang terjangkit penyakit menular dan berbahaya seperti HIV/AIDS, TBC dan penyakit infeksi lainnya, pemanfaatan terhadap pasal-pasal pelindung di berbagai negara berkembang dan terbelakang juga kelihatan semakin meningkat. Brazil, Afrika Selatan dan India adalah contoh negaranegara yang sangat peduli terhadap arti penting pasal-pasal pelindung dan telah menerapkan ketentuan tersebut untuk mengatasi masalah domestik di bidang kesehatan masyarakat. Sedangkan negara-negara yang terletak di wilayah Asia Tenggara juga sudah mengantisipasi adanya kemungkinan epidemik penyakit HIV/ AIDS dengan membuat berbagai macam peraturan pemerintah yang memungkinkan untuk memproduksi versi generik dari obat-obatan tertentu yang masih dilindungi paten baik melalui lisensi wajib (compulsory license) maupun melalui pelaksanaan paten oleh pemerintah (government use).

Pada tahun 2004, pemerintah Indonesia menerapkan pelaksanaan paten oleh pemerintah untuk pertama kalinya sejak dibuatnya UU Paten nasional tahun 1989. Melalui Keputusan Presiden No.83 tahun 2004, pemerintah memutuskan untuk melaksanakan sendiri produksi obat generik dari beberapa obat yang masih dilindungi paten karena adanya kebutuhan yang sangat mendesak untuk mengatasi penyebaran yang sangat pesat dari penyakit HIV/AIDS di Indonesia. Keppres tersebut menjadi dasar hukum bagi pelaksanaan government use di Indonesia terhadap dua buah jenis obat antiretroviral, yaitu Nevirapin, dengan pemegang paten Boehringer Ingelheim (BI) dan nomor paten ID 0001338 serta Lamivudin, dengan 
pemegang paten Biochem Pharma INC dan nomor paten ID 0002473. Nevirapin akan diproduksi oleh pemerintah Indonesia selama 7 tahun, sedangkan Lamivudin akan diproduksi dalam jangka waktu 8 tahun. Pemerintah juga akan memberikan imbalan berupa pembayaran royalti kepada para pemegang paten dengan ketentuan $0.5 \%$ dari nilai penjualan bersih obat-obatan tersebut.

Mengingat penerapan pasal-pasal pelindung sangat berpotensi untuk menimbulkan konflik hukum dengan negara-negara maju, paper ini akan mengkaji beberapa hal penting di seputar pelaksanaan pasal tersebut, seperti analisa terhadap konsistensi pasal-pasal pelindung yang termuat dalam UU Paten Indonesia dengan perjanjian TRIPS dan evaluasi terhadap pasal-pasal pelindung tersebut dalam UU Paten Indonesia dari perspektif efektivitasnya dalam menjalankan fungsi sebagai pelindung terhadap dampak negatif perjanjian TRIPS di sektor kesehatan masyarakat. Status dan profil kesehatan Indonesia juga akan dipaparkan sebelumnya di dalam paper ini untuk memberikan gambaran yang melatarbelakangi perlunya menerapkan pasal-pasal pelindung tersebut di Indonesia. Di bagian akhir, paper ini juga menganjurkan beberapa upaya penyempurnaan sebagai sebuah solusi untuk mewujudkan pelaksanaan pasal-pasal pelindung yang efektif dan efisien.

\section{Profil Kesehatan Indonesia}

Kebijakan kesehatan masyarakat di Indonesia berkembang secara dinamis dari tahun ke tahun. Pada awal kemerdekaan di tahun 1945, sektor ini sangat ditelantarkan karena perhatian pemerintah lebih tertuju kepada upaya untuk mempertahankan kemerdekaan dan kedaulatan Indonesia dari serangan atau agresi militer Belanda. ${ }^{1}$

Seiring dengan perkembangan waktu kebijakan itu sendiri telah berubah dari kebijakan yang tidak terlalu diperhatikan menjadi sebuah sektor yang menduduki posisi yang sangat penting di dalam kerangka pembangunan Indonesia. Melalui perubahan paradigma ini, masyarakat menuntut pemerintah untuk memberikan pelayanan kesehatan yang lebih baik kepada warganya serta mengupayakan akses yang lebih baik terhadap obat yang murah dan terjangkau, menjamin ketersediaan obat-

${ }^{1}$ Lihat Depkes RI , 1978, Sejarah Kesehatan Nasional Indonesia Jilid 1, Jakarta, Depkes, hlm 16-19. 
obat esensial, meningkatkan kualitas sumber daya manusia di sektor kesehatan masyarakat serta memantau berbagai fasilitas kesehatan dan penggunaan obat yang rasional. Semua harapan ini telah diupayakan untuk tercakup di dalam berbagai program di sektor kesehatan masyarakat di Indonesia. Untuk mengetahui lebih lanjut tentang status dan profil kesehatan masyarakat di Indonesia, berikut ini akan dipaparkan beberapa aspek penting dari kesehatan masyarakat di Indonesia, seperti profil geografi, ekonomi, fasilitas kesehatan, pola penyakit, jenis obat-obatan yang dibutuhkan dan desentralisasi kesehatan.

\section{Profil Geografi}

Pada tahun 2001, lebih dari separuh orang Indonesia tingal di Jawa dan Bali (61.8\%) dan diikuti oleh Sumatera (19,43\%), Sulawesi $(7,25 \%)$, Kalimantan (5,51\%) dan Nusa Tenggara, Maluku serta Papua (5,94\%). ${ }^{2}$ Secara geografis, $43,13 \%$ penduduk Indonesia tinggal di area perkotaan dan $56,87 \%$ tinggal di pedesaan. ${ }^{3}$

\section{Profil Ekonomi}

Dari tahun 1966 sampai dengan 1998, Indonesia pernah mencapai pertumbuhan ekonomi yang mengesankan. Sebagai contoh pada era tahun 1960-an, GDP per kapita Indonesia adalah US\$70 dan sekitar tahun 1996 melonjak menjadi US \$1,000. ${ }^{4}$ Pencapaian ini berhasil meyakinkan banyak orang yang memprediksikan Indonesia akan menjadi salah satu macan ekonomi di Asia ${ }^{5}$ dengan pertumbuhan pasar yang sangat cepat. ${ }^{6}$ Meskipun demikian, Indonesia sangat dipengaruhi oleh krisis ekonomi pada tahun 1997. Akibatnya, pertumbuhan ekonomi Indonesia turun sebesar 0,3\% di pertengahan tahun 1999 .

${ }^{2}$ Depkes RI (The Ministry of Health), Profil Kesehatan Indonesia 200,1 tersedia di http:/ / www.depkes.go.id/ downloads/Narasi2001.pdf, hal. 59 (2002); the Embassy of India in Jakarta, Indonesia, hal. 66, The Market for Pharmaceutical Products and Materials in Indonesia, prepared by PT Data Consult, tersedia di http: // www.embassyofindiajakarta.org/Pharmaceutical_mkt_survey.pdf

${ }^{3}$ Ibid., hlm. 4.

${ }^{4}$ Ibid., hlm. 1.

${ }^{5}$ Henri Myrttinen, Indonesian Economic Policy at Crossroads?, available at:// www.kepa.fi/ international/English/information/newsletter/2003/3472, hal. 1.

${ }^{6}$ Wikipedia, Wikipedia, Economy of Indonesia, hal. 1, tersedia di http:// 
Sekitar tahun 2005, pertumbuhan ekonomi kembali meningkat menjadi $5.6 \%$ dan pendapatan GDP percapita menjadi US\$3.700. Jumlah angkata kerja sebesar 98 juta, terdiri dari a) pekerja yang diupah dan pegawai yang memperoleh penghasilan $(36,2 \%)$; b) wiraswasta $(51.9 \%)$; c) majikan $(3,4 \%)$ dan; d) usaha keluarga $(8,5 \%)^{7}$. Tingkat pengangguran sebesar $10,3 \%$ pada tahun $2005 .{ }^{8}$ Namun, pendapatan per kapita Indonesia masih rendah, yaitu sekitar US\$ 700. ${ }^{9}$ Jumlah penduduk miskin sebesar 37,1 juta pada tahun 2001. Sebanyak 8,5 juta dari angka tersebut, tinggal di daerah perkotaan sedangkan sisanya sebesar 28,6 juta tinggal di wilayah pedesaan. ${ }^{10}$

\section{Fasilitas Kesehatan}

Sampai tahun 2001, Indonesia mempunyai sekitar 1.179 rumah sakit dengan jumlah tempat tidur sebanyak 127.217. Rasio jumlah pasien dengan tempat tidur adalah 61/100.000 orang. Dari keseluruhan rumah sakit tersebut, sekitar 598 (50,7\%) adalah rumah sakit pemerintah dan $581(49.3 \%)$ adalah rumah sakit swasta. ${ }^{11}$ Akses terhadap kesehatan masyarakat untuk masyarakat miskin adalah sebesar 20\%. Angka ini belum memadai dan perlu ditingkatkan. Untuk meningkatkan akses terhadap pelayanan kesehatan tersebut, pemerintah telah membangun pusat kesehatan, pos-pos kesehatan dan pos kesehatan keliling. Pada tahun 2001, terdapat sekitar 7.277 pusat kesehatan, 21,587 pos kesehatan dan 5800 pos kesehatan keliling. Tahun 2001, rasio pusat kesehatan dengan jumlah penduduk adalah 3.5: 100,000, untuk pos kesehatan 10.5:100,000 dan pos kesehatan keliling 0.8: 100,000. ${ }^{12}$

\section{Sumber daya manusia di sektor kesehatan}

Selama tahun 1986-1999, 27.421 dokter diluluskan oleh 29 universitas di seluruh Indonesia. Dari tahun 1988 sampai tahun 2001, kira-kira 5.886

${ }^{7}$ Hasbullah Thabrany, et al, Social Health Insurance in Indonesia: Current Status and the Plan for National Health Insurance (Annex 3), presented in Social Health Insurance Workshop, WHOSEARO, New Delhi, March 13-15, 2003, hal. 146, tersedia di http:/ /w3.whosea.org/LinkFiles/Social_Health_Insurance_an3.pdf (last visited 03/06/ 06).

${ }^{8}$ Wikipedia, supra note 6 , hlm. 1.

${ }^{9}$ Hasbullah Thabrany et al, supra note 7, hlm. 146.

${ }^{10}$ Depkes RI (The Ministry of Health), supra 2, hlm. 60.

${ }^{11}$ Ibid., hlm. 67.

${ }^{12}$ Ibid., hlm. 65-66. 
atau $1 / 5$, telah selesai dididik untuk menjadi dokter spesialis. Dari tahun 1988 sampai dengan tahun 1998, 7983 dokter gigi berhasil diluluskan. Antara tahun 1990 sampai tahun 1998, ada sekitar 2924 lulusan sarjana kesehatan masyarakat. ${ }^{13}$

Penyebaran tenaga medis di Indonesia masih belum merata. Kebanyakan tenaga kesehatan memilih untuk ditempatkan di Pulau Jawa dengan alasan pulau tersebut lebih banyak penduduknya, lebih berkembang dan lebih maju. Alasan lainnya yang diajukan adalah karena di Pulau Jawa banyak terdapat fasilitas pendidikan kesehatan seperti fakultas kedokteran dan kedokteran gigi. ${ }^{14}$ Sebaliknya pulau-pulau tertentu seperti Kalimantan dan Papua tidak begitu menarik minat para tenaga kesehatan muda. Sebagai contoh, rasio dokter spesialis di pulau Jawa dibandingkan dengan daerah-daerah lainnya di Indonesia adalah sekitar 7403:1802 (4.1: 1). Di Jakarta, ada sekitar 2441 dokter spesialis atau $27 \%$ dari semua dokter spesialis di Indonesia. ${ }^{15}$

Pemerintah mencoba untuk mendorong para dokter dan dokter gigi untuk ditempatkan di daerah-daerah terpencil selain pulau Jawa dengan menwarkan berbagai fasilitas pendukung seperti gaji yang lebih tinggi serta dijanjikan fasilitas perumahan. Namun penyebaran yang tidak merata terhadap dokter dan dokter gigi masih terus berlangsung. ${ }^{16}$

Pemerintah mempunyai kewajiban untuk memeriksa dan mengawasi pemberian ijin terhadap para tenaga kesehatan sebelum dapat berpraktek di seluruh wilayah Indonesia. Untuk para bidan, pemerintah mengeluarkan Keputusan MenKes No.900/MENKES/SK/VII/2002 yang mensyaratkan seorang bidan untuk memenuhi persyaratan administrasi dan teknis sebelum menerima ijin untuk berpraktek. Mereka harus menyerahkan surat permohonan untuk mendapatkan ijin tersebut kepada pemerintah dimana mereka akan membuka praktek. Peraturan ini juga berlaku terhadap profesi kesehatan lainnya seperti perawat gigi dan asisten apoteker.

${ }^{14}$ Lihat Kenneth M. Chomitz et al, What Do Doctors Want? Developing Incentives for Doctors to Serve in Indonesia's Rural and Remote Areas, hal. 2-3, available at http:/ / www.worldbank.org/html/dec/ Publications/ Workpapers/ WPS1800series/ wps1888/wps1888.pdf

${ }^{15}$ Warko Karnadihardja dan Kiki Lukman, Antisipasi Terhadap Krisis Ketenagaan Dokter Spesialis in Indonesia Menjelang Tahun, hal. 5, tersedia di http:// dokter.indo.net.id / krisis.doc.

${ }^{16}$ Lihat Kenneth M. Chomitz et al, supra note 14, hlm. 2-3; lihat juga Warko 
Dokter, dokter gigi, dokter spesialis dan dokter gigi spesialis harus melakukan magang terlebih dahulu di sebuah rumah sakit selama jangka waktu tertentu sebelum dapat membuka praktek di Indonesia. Sesudah lulus dari ujian pelatihan, mereka akan diberi ijin untuk berpraktek. Namun sebelumnya mereka harus melamar ke Konsil Kedokteran Indonesia untuk mendapatkan sertifikat pendaftaran (Pasal 29 UU No. 29 tahun 2004 tentang Praktek Kedokteran). Selanjutnya mereka menyerahkan sertifikat tersebut sebagai bukti untuk membuka praktek di wilayah yang telah mereka tentukan setelah sebelumnya memperoleh rekomendasi dari organisasi profesi. Setelah proses ini, mereka akan memperoleh ijin praktek dari kepala daerah dimana mereka akan ditempatkan (Pasal 36,37 and 38).

Organisasi profesi bertanggung jawab terhadap pembuatan dan penegakan etika profesi. Asosiasi profesi mengatur dan menegakkan kode etik tersebut diantara para anggotanya terhadap permasalahan tertentu, misalnya kasus malpraktek. Kode etik di bidang Kedokteran mensyaratkan dokter untuk memdahulukan kepentingan pasien dibandingkan dengan kepentingan mereka sendiri (Pasal 3), menjaga kerahasiaan data pasien (Pasal 13), memberikan bantuan darurat kepada para pasien (Pasal 13) dan untuk memenuhi kewajiban lainnya yang berkaitan dengan hak-hak para pasien. ${ }^{17}$

Ikatan Dokter Indonesia sebagai asosiasi profesi sering dikritik masyarakat berkaitan dengan tugas mereka dalam menegakkan kode etik profesi ${ }^{18}$ termasuk laporan keputusan terhadap penyelesaian kasus-kasus kode etik ${ }^{19}$ dan pengungkapan terhadap keputusan tersebut. ${ }^{20}$ Solidaritas di antara sesama tenaga medis tampaknya sangat kuat terutama saat menghadapi kasus-kasus malpraktek. Hal ini berpotensi untuk membuat penegakan kode etik menjadi tidak efektif. ${ }^{21}$ Tanpa adanya keseriusan dan sikap yang objektif

${ }^{17}$ Azrul Azwar, Beberapa Catatan Tentang UU Perlindungan Konsumen dan Dampaknya Terhadap Pelayanan Kesehatan, hal. 2-3, tersedia di http:// www.idionline.org/arsip/jurnal/beberapa_catatan_tentang _UU_Perlindungan_ Konsumen.pdf.

${ }^{18}$ Lihat Chrisdiono M. Achadiat, Perlukah MKEK "Bersidang" (Juga)? Kompas, 26 July 2002, at 1-2, available at http://www.kompas.com/kompas-cetak/0207/ 26/ iptek/perl37.htm

${ }^{19}$ Wirawan, Kasus Malpraktik Antara Kehormatan Profesi Dan Kepastian Hukum, Teropong, Suplemen Pikiran Rakyat, 4 Oktober 2004, at 4, tersedia di http:// www.pikiran-rakyat.com/cetak/1004/04/teropong/ konsul_hukum.htm.

${ }^{20}$ Chrisdiono M. Achadiat, supra note 18, hal. 1; Suara Merdeka, Majelis Kode Etik Bukan Untuk Membela Dokter, hal. 1, tersedia di http:/ / www.suaramerdeka.com/ harian/0110/06/ kot10.htm (October, 6 2001). 
dan independen, kode etik profesi yang dibuat untuk menegakkan norma diantara para dokter hanya akan menjadi formalitas belaka dan tidak akan mencapai tujuan seperti yang tertuang di dalam kode etik itu sendiri.

\section{Pendidikan Kesehatan}

Pendidikan tenaga kesehatan di Indonesia pada awalnya diperuntukkan untuk menghasilkan asisten yang akan membantu menangani wabah campak yang sedang berkecamuk pada saat $i^{22}$ dan dilakukan di bawah pengawasan pemerintah kolonial Belanda. Selama pendudukan Jepang, sekolah kedokteran yang telah dibangun pemerintah Belanda pada era tahun 1880-an diubah menjadi Ikadaigaku. Di Semarang pemerintah kolonial Jepang membangun sekolah perawat dan sebuah pusat pelatihan untuk asisten dokter atau Hojoi. Kebanyakan dokter berkebangsaan Indonesia yang dididik oleh pemerintah Belanda dipindahkan oleh pemerintah Jepang ke unit-unit militer. ${ }^{23}$

Sesudah kemerdekaan, pemerintah Indonesia secara bertahap membangun berbagai universitas yang memiliki fakultas kedokteran ${ }^{24}$, farmasi dan keperawatan untuk mendidik dokter dan tenaga paramedik. Kebijakan ini diambil untuk mengatasi kekurangan tenaga kesehatan di Indonesia. ${ }^{25}$

Setelah melewati masa-masa yang sangat sulit selama 60 tahun, pendidikan kesehatan di Indonesia mulai berkembang secara pesat baik dalam bentuk jumlah maupun kualitasnya. Sebagian besar provinsi sudah memiliki universitas baik negeri maupun swasta dengan fakultas kedokteran di dalamnya. Bahkan beberapa diantaranya juga memiliki fakultas kesehatan masyarakat, farmasi dan keperawatan. Sistim pendidikan kesehatan di Indonesia dibagi ke dalam berbagai jenis pendidikan.

${ }^{22}$ Depkes (I), supra note 10, hlm. 12-13.

${ }^{23}$ Ibid., hlm. 14-15.

${ }^{24}$ Fakultas Kedokteran UGM Yogyakarta didirikan tanggal 19 Desember 1949 (lihat UGM Website, Sejarah UGM, tersedia di http://www.ugm.ac.id/ content.php?page $=0 \&$ display=2) dan diikuti oleh Fakultas Kedokteran Universitas Indonesia tanggal 10 Januari 1950. Fakultas Kedokteran UI adalah kelanjutan dari Geneeskundige Hogeschool di Batavia berdasarkan peraturan Koloni Belanda (Program Pasca Sarjana Universitas Indonesia, Sejarah Pasca Sarjana UI, http:/ / pps.ui.ac.id/ sejarah.htm). Sesudah pendirian kedua fakultas Kedokteran tersebut, beberapa Universitas negeri dengan fakultas Kedokteran di dalamnya mulai didirikan oleh pemerintah di beberapa propinsi di antaranya di Jawa, Sumatera, Bali and Sulawesi.

${ }^{25}$ Lihat Depkes (II), 1980, Sejarah Kesehatan Nasional Indonesia Jilid 2, Jakarta, Depkes, 
Departemen kesehatan juga menyediakan sekolah-sekolah khusus untuk menghasilkan tenaga paramedik seperti bidan, perawat dan profesi paramedis lainnya. Sedangkan Departemen Pendidikan Nasional membina universitas-universitas yang mendidik tenaga dokter, dokter gigi, tenaga kesehatan masyarakat dan apoteker. ${ }^{26}$

Terdapat sekitar 32 politeknik di seluruh wilayah Indonesia yang berada di bawah Departemen Kesehatan. ${ }^{27}$ Terdapat sekitar 645 lembaga yang bertugas mendidik tenaga paramedik dimana sekitar 2/3 (450 sekolah atau 69,77\%) adalah sekolah perawat. ${ }^{28}$ Dari tahun 1997 sampai dengan tahun 2001, terdapat kenaikan jumlah lulusan perguruan tinggi yang melatih paramedik, dan ada kecenderungan bahwa jumlah ini akan semakin menaik. ${ }^{29}$

Naiknya angka lulusan di sektor kesehatan masyarakat tidak dapat dilepaskan dari permintaan negara-negara lain kepada Indonesia untuk mengirimkan sejumlah tenaga medis, terutama perawat ke sejumlah negara seperti Masyarakat Eropa, negara-negara Asia Tenggara, Australia, Jepang dan beberapa negara Timur Tengah, yang mengalami kekurangan tenaga perawat. ${ }^{30}$ Sebagai contoh, AS dapat menyediakan sekitar 50.000 kesempatan kerja kepada para perawat di seluruh dunia, sementara Inggris menyediakan sebesar 10.000 peluang kerja kepada para perawat setiap tahunnya, khususnya perawat dari Filipina. ${ }^{31}$

Yang menjadi permasalahan adalah kebanyakan tenaga perawat Indonesia belum memenuhi standard internasional untuk bekerja sebagai perawat asing di negara-negara lain. Hanya sedikit dari sekian banyak perawat Indonesia yang dapat menembus pasar kerja di luar negeri seperti negara-negara Asia Tenggara dan Timur Tengah. ${ }^{32} \mathrm{Hal}$ ini disebabkan karena kemampuan bahasa Inggris yang kurang memadai. Skor minimum bahasa Inggris (National License Examination/NLEX) untuk dapat bekerja di AS

\footnotetext{
${ }^{26}$ Lihat Depkes RI (The Ministry of Health), supra note 22, at 88-89.

${ }^{27}$ Ibid., hlm. 88.

${ }^{28}$ Ibid.

${ }^{29}$ Ibid., hlm. 89.

${ }^{30}$ PUSDIKNAKES (1), Terbuka Lebar, Peluang Kerja Perawat di Amerika, Arab dan
} Eropa , hal. 1, tersedia di http:/ / www.pusdiknakes.or.id/news/ragam.php3?id=10; lihat PUSDIKNAKES (2), Perawat, Dokter Filipina Berbondong-bondong ke Luar, hal. 1, tersedia di http://www.pusdiknakes.or.id/news/ utama.php3?id=26; lihat PUSDIKNAKES (3), Gaji Dokter Indonesia di Saudi Arabia Rp. 10 Juta, hal. 1, tersedia di http:/ / www.pusdiknakes.or.id/news / utama.php3?id=14.

${ }^{31}$ Ibid.

${ }^{32}$ Ibid. 
adalah antara 70-80 dan negara-negara Eropa mensyaratkan skor sekitar 50-70. Tetapi, mayoritas perawat Indonesia hanya memiliki skor sekitar 40. Tidak mengherankan, para perawat Indonesia, tidak mampu menembus pasar kerja luar negeri dan kalah bersaing dengan para perawat Filipina. ${ }^{33}$ Berdasarkan catatan, ada sekitar 60.000 perawat Indonesia yang sedang mencari kerja atau menjadi pengangguran saat ini. ${ }^{34}$ Jumlah para perawat tersebut tidak dapat diserap oleh pasar kerja yang ada di Indonesia.

\section{Pola penyakit yang umum dan obat yang sangat dibutuhkan}

Penyakit menular seperti TBC dan Malaria adalah salah satu penyebab kematian terbesar di Indonesia, sementara penyakit tidak menular seperti jantung dan penyakit kronis juga meningkat, khususnya di wilayah perkotaan. Penyakit lainnya seperti HIV/AIDS juga menampakkan peningkatan penyebaran yang sangat signifikan. ${ }^{35}$

Penyakit TBC adalah penyebab kematian ketiga di Indonesia selama tahun 2000-2001 dan telah menjadi salah satu dari sepuluh penyakit penyebab kematian terbesar di rumah sakit-rumah sakit di Indonesia. Setiap tahun diperkirakan terdapat sekitar 262.000 orang yang terjangkit penyakit TBC dan 140.000 diantaranya meninggal setiap tahunnya. Organisasi Kesehatan Dunia (WHO) mengidentifikasikan Indonesia sebagai negara ketiga paling besar jumlah penderita TBC di seluruh dunia. ${ }^{36}$ Malaria juga merajalela di Indonesia tetapi kebanyakan kasus Malaria ditemukan di luar wilayah Jawa dan Bali. Sekitar 35\% penduduk Indonesia tinggal di wilayah endemik Malaria. Pada tahun 2001, terdapat sekitar 62 kasus Malaria per 100.000 penduduk. ${ }^{37}$

Dikarenakan perubahan gaya hidup, banyak penduduk Indonesia menderita penyakit kronis tidak menular seperti stroke, jantung, kanker, kelainan metabolisme, dan penyakit-penyakit peredaran darah. ${ }^{38}$ Pada

\footnotetext{
${ }^{33}$ Ibid., hlm. 1-2.

${ }^{34}$ PUSDIKNAKES (3), supra note 30, at 1.

${ }^{35} \mathrm{WHO}$, Macroeconomics and Health - Indonesia Country Profile, hal. 3, tersedia di http://www.who.int/macrohealth/action/en/rep04_indonesia.pdf (last visited 03/ 06/06).; lihat juga ADB, Supporting Health Systems in Indonesia, CGI Health Working Group Meeting, 10 December 2003, Jakarta, hal. 1, tersedia di http:// Inweb18.Worldbank.org/eap/eap.nsf/Attachments/CGI-1203-ADB-health/\$File/ ADB-Health.pdf (last visited 03/06/06); Depkes RI, supra note 26, hal. 37-39,48.

${ }^{36}$ Depkes RI, Ibid., hlm. 39.

${ }^{37}$ Ibid., hlm. 37-38.
} 
tahun 2000, penyakit stroke, jantung, dan diabetes tercatat sebagai tiga dari 10 penyakit tidak menular yang menyebabkan kematian yang paling tinggi di Indonesia. ${ }^{39}$ Pada tahun 2001, terdapat 2.593 kasus HIV dan 671 kasus AIDS telah dilaporkan terjadi di Indonesia. Ada sekitar 80.000 sampai 120.000 orang telah terinfeksi penyakit HIV. ${ }^{40}$

Sekitar $45 \%$ obat-obatan yang terdapat di dalam Daftar Obat Esensial National (DOEN) ${ }^{41}$, termasuk obat-obatan untuk penyakit Malaria, TBC, $\mathrm{HIV} / \mathrm{AIDS}$ dan penyakit tidak menular seperti penyakit-penyakit kronis dilindungi paten. Banyak penduduk Indonesia membutuhkan obat-obatan yang lebih baru, selain obat generik yang tersedia di dalam daftar DOEN karena banyak penduduk yang telah resisten terhadap obat-obatan generik untuk penyakit Malaria dan TBC. ${ }^{42}$ Sebagai contoh, obat-obatan untuk penyakit Malaria yang sudah resisten adalah Chloroquine, sebuah obat yang murah dan dapat diperoleh dengan mudah. Obat jenis ini telah teridentifikasi sebagai obat yang resisten terhadap Malaria sejak tahun 1974 di seluruh wilayah Indonesia. Ini berarti bahwa kebanyakan penderita Malaria tidak akan dapat disembuhkan jika mengkonsumsi Chloroquine saja. Oleh karena itu, kebanyakan penderita Malaria di Indonesia membutuhkan obat-obatan yang lebih baru. ${ }^{43}$

\section{Desentralisasi Kesehatan}

Tujuan desentralisasi kesehatan adalah memberikan kewenangan yang lebih banyak kepada pemerintah daerah untuk memutuskan segala sesuatu yang berkaitan dengan keadaan kesehatan di daerahnya. Sejak tahun 2001, pemerintah pusat telah menyerahkan otonomi kepada pemerintah daerah untuk menangani berbagai macam pembangunan di daerahnya berdasarkan sistim desentralisasi di berbagai sektor seperti

${ }^{39}$ Ibid., hlm. 78; Depkes RI, supra note 36, hlm. 48.

${ }^{40}$ Depkes RI (The Ministry of Health); Id., hal. 39-40.

${ }^{41}$ Depkes RI, 2005, Kebijakan Obat Nasional/KONAS (The National Drug Policy draft), hlm. 9, tersedia di http:/ / www.depkes.go.id/downloads/Konas.pdf, 6 (September 23, 2005).

${ }^{42} \mathrm{WHO}$, State of the World's Vaccines and Immunization, Geneva, WHO, hal. 60, tersedia di http:/ / www .unicef.org/publications/files/pub_sowvi_en.pdf (2002).

${ }^{43}$ UNDP. Memerangi HIV/AIDS, Malaria and Penyakit Menular Lainnya (dalam Laporan Perkembangan Pencapaian Tujuan Pembangunan Millenium Indonesia), hlm. 70, tersedia di http://www.undp.or.id/ pubs/imdg2004/BI/IndonesiaMDG_BI_Goal6. pdf. 
perencanaan pembangunan, penyediaan fasilitas umum, kontrol lingkungan, pembangunan kesehatan dan sektor-sektor lainnya. ${ }^{44}$ Ada sebelas kewajiban yang harus dilaksanakan oleh pemerintah daerah di sektor kesehatan masyarakat, diantaranya pembiayaan pelayanan kesehatan, pemberian ijin kepada distributor obat, pengawasan terhadap penyakit endemik, penyediaan obat-obat esensial dan pembuatan standardisasi akreditasi fasilitas kesehatan. ${ }^{45}$

Sesudah 5 tahun pelaksanaan desentralisasi kesehatan di Indonesia, terdapat beberapa permasalahan yang berpotensi menghambat tujuan desentralisasi tersebut. Sebagai contoh konflik antara pemerintah pusat dan daerah berkaitan dengan pemberian ijin bagi pendirian rumah sakit baru di daerah, program asuransi pelayanan kesehatan bagi rakyat miskin, pengawasan epidemik dan pembagian tenaga kesehatan di daerah. Dari beberapa permasalahan tersebut, tampaknya konflik yang terkait dengan prosedur pendirian rumah sakit di daerah sebagai sebuah masalah yang terus berkembang dan serius. Pemerintah pusat beranggapan bahwa ijin pendirian rumah sakit seharusnya diberikan oleh pemerintah pusat. Pemerintah pusat khawatir bahwa pemerintah daerah akan menggunakan ijin tersebut sebagai sarana untuk menaikkan restribusi terhadap anggaran pemerintah daerah. ${ }^{46}$

Berkaitan dengan anggaran kesehatan, tampaknya pemerintah daerah tidak terlalu memprioritaskan sektor kesehatan masyarakat. Kesehatan masyarakat di bawah era desentralisasi menjadi bidang yang diterlantarkan. Hal ini terbukti dengan kecilnya jumlah anggaran untuk sektor kesehatan masyarakat sesudah digalakkannya otonomi daerah. ${ }^{47}$

${ }^{44}$ Pasal 13, UU No.32 tahun 2004 tentang Pemerintahan Daerah.

${ }^{45}$ Pasal 2 (10), PP No.25 tahun 2000 tentang Kewenangan Propinsi sebagai Sebuah Wilayah Otonom.

${ }^{46}$ Center for Health Service and Management, Gadjah Mada University, Laporan Seminar Nasional 4 Tahun Desentralisasi Kesehatan di Indonesia, Hotel Marannu, Makassar, 7-9 Juni 2005, hal..4, tersedia di http://www. desentralisasikesehatan.info/doc/LapSemNas4thn DesKes.pdf (last visited 09/14/06).

${ }^{47}$ Depkes RI, supra note 40, hal. 93; Buletin Desentralisasi Kesehatan, Desentralisasi Kesehatan dan Perubahan Peran Pemerintah dalam Pembiayaan, Volume II/02/2004, hlm. 


\section{Evaluasi terhadap the TRIPS safeguards yang diatur di dalam UU Paten Indonesia}

Profil kesehatan Indonesia yang telah dipaparkan di dalam bagian terdahulu diharapkan dapat menjadi penghubung terhadap permasalahan yang akan didiskusikan di dalam bagian ini. Pemahaman yang lebih konprehensif terhadap permasalahan di bidang kesehatan masyarakat, akan membantu menjawab pertanyaan mengapa pasal-pasal pelindung memiliki peran yang sentral di dalam pembangunan kesehatan Indonesia.

Paparan berikut ini akan mengupas apakah pasal-pasal pelindung tersebut sudah sesuai dengan standar perjanjian TRIPS dan kelemahankelemahan apakah yang harus diperbaiki oleh pemerintah Indonesia terhadap pasal-pasal tersebut sehingga di masa yang akan pelaksanaannya dapat mencapai sasaran.

\section{Impor Paralel (Parallel imports)}

Impor paralel diatur di dalam Pasal 135 (a) UU Paten tahun 2001. Impor paralel didefinisikan sebagai importasi sebuah produk farmasi yang telah dipatenkan dan dipasarkan di negara lain. Berdasarkan ketentuan tersebut, impor paralel dianggap sebagai sebuah perbuatan yang legal. Tujuan utama pengaturan impor paralel di Indonesia adalah untuk mendapatkan akses yang lebih baik terhadap obat yang lebih murah dan terjangkau. Penggunaan impor paralel tergantung kepada kebijakan pemerintah untuk mendukung ketersediaan dan keterjangkauan obat bagi masayarakat luas (Pasal 135 [a]). Impor paralel yang diatur di dalam UU Paten Indonesia ditujukan pada produk-produk farmasi yang telah dipasarkan dengan harga yang melampaui harga pasar internasional.

\section{a. Evaluasi terhadap peraturan impor paralel Indonesia: perspektif perjanjian TRIPS}

Berdasarkan perspektif perjanjian TRIPS, peraturan impor paralel yang terdapat di dalam UU Paten Indonesia sudah sesuai dengan standard internasional. Melalui peraturan domestik Indonesia, pemerintah mengijinkan terjadinya importasi ke Indonesia tanpa ijin dari pemegang paten dengan dasar teori pelepasan (theory of exhaustion). Pasal 135 (a) UU Paten Indonesia mengijinkan terjadinya impor paralel dengan dua

syarat 1) pengimporan harus dilakukan secara sah dan 2) produk yang akan dijadikan target impor paralel adalah produk yang terbukti relatif 
lebih mahal dibandingkan dengan produk yang sama di pasar internasional.

Pemerintah Indonesia juga mensyaratkan beberapa aspek penting untuk dipertimbangkan sebelum mengijinkan impor paralel. Pertama, pengimporan harus sesuai dengan peraturan mengenai importasi di tingkat nasional dan internasional. Sebaliknya, importasi yang dilakukan secara melawan hukum dilarang oleh Pasal 135 (a) UU Paten Indonesia. Kedua, pelaksanaan impor paralel hanya dikenakan terhadap produk farmasi yang relatif lebih mahal dibandingkan dengan produk serupa di pasar internasional atau di negara-negara lain. Dengan kata lain, impor paralel tidak diperuntukkan untuk semua jenis produk farmasi yang beredar secara luas di pasar nasional dan internasional. ${ }^{48}$

\section{b. Kritik dan saran terhadap peraturan impor paralel Indonesia}

Peraturan impor paralel Indonesia sangat umum dan memungkinkan terjadinya multi interpretasi. Saran-saran berikut ini akan memperbaiki peraturan tersebut yang akan difokuskan pada beberapa hal seperti, penjelasan secara rinci tentang aktivitas yang tercakup di dalam impor paralel dan peran serta tanggung jawab institusi yang akan melaksanakan impor paralel tersebut.

\section{i) Peninjauan ulang terhadap institusi yang terlibat}

Peraturan impor paralel Indonesia tidak menyebutkan secara jelas institusi mana yang bertanggung jawab terhadap pelaksanaan impor paralel. Apakah pelaksanaannya akan dilaksanakan oleh Departemen Perdagangan, koordinasi antara Departemen Perdagangan dan Dinas Bea Cukai, atau melibatkan kerjasama intra departemen yang lebih luas, misalnya koalisi khusus dari kedua departemen tersebut dan ditambah dengan institusi lain yang terkait, seperti Departemen Kesehatan dan Ditjen HaKI?

\footnotetext{
${ }^{48}$ Lihat Tim Lindsey et al (eds), 2002, Hak Kekayaan Intelektual Suatu Pengantar,
} 


\section{ii) Latihan dan Pengawasan}

Latihan dan pengawasan terhadap para aparatur pemerintah yang akan melaksanakan impor paralel perlu dilakukan. Berdasarkan penelitian lapangan pada tahun 2006, terbukti bahwa banyak aparat yang berasal dari departemen terkait seperti Departemen Perdagangan tidak mengetahui tentang impor paralel dan tujuan dari impor paralel serta prosedur impor paralel. ${ }^{49}$ Kebanyakakan aparat berpendapat bahwa impor paralel adalah sama dengan prosedur importasi secara umum, dari pada importasi yang sifatnya khusus dan hanya dibatasi terhadap produk farmasi yang lebih mahal dibandingkan dengan harga daripada produk serupa di pasar internasional. ${ }^{50}$

\section{iii) Ketersediaan akan Tenaga Ahli}

Informasi dan keputusan seharusnya didasarkan pada keahlian yang tersedia di berbagai institusi terkait. Depkes misalnya berwenang untuk menentukan produk farmasi apa saja yang memenuhi syarat untuk diterapkan impor paralel. Sedangkan Ditjen HaKI dapat membantu pelaksanaan impor paralel dengan menyediakan informasi mengenai produk farmasi yang telah dilindungi paten di Indonesia dan kantor bea cukai bertugas untuk memeriksa apakah prosedur pelaksanaan impor paralel telah sesuai dengan peraturan tentang ekspor impor baik secara nasional maupun secara internasional.

\section{iv) Penjelasan secara spesifik tentang impor paralel}

Pasal 135 (a) tidak menjelaskan secara detail tentang prosedur dan persyaratan administrasi dan teknis dari impor paralel. Sebagai contoh, apakah untuk melaksanakan impor paralel diperlukan persyaratan tambahan selain persyaratn importasi secara umum?

\section{v) Target impor paralel}

Untuk memaksimalkan fungsi impor paralel, pemerintah seharusnya menjelaskan prosedur tentang produk farmasi yang menjadi prioritas pemerintah untuk dijadikan target impor paralel. Selain itu, pemerintah

\footnotetext{
${ }^{50}$ Ibid.

${ }^{49}$ Wawancara dengan beberapa responden dari sebuah instansi pada bulan
} 
juga perlu membuat daftar jenis obat yang menjadi target tersebut berikut dengan perlindungan yang akan diberikan terhadap pemegang paten dari produk obat tersebut.

\section{Bolar provisions}

Bolar provisions diatur di dalam Pasal 135 (b) UU Paten Indonesia tahun 2001. Pasal tersebut mengijinkan perusahaan yang ada di Indonesia untuk menyiapkan pembuatan obat generik bagi obat yang sudah dipatenkan, dua tahun sebelum perlindungan paten obat tersebut berakhir. Bolar provision juga mengijinkan perusahaan generik lokal untuk melakukan pengujian dan mempersiapakan produksi versi generik dari obat yang dipatenkan dengan tujuan untuk mendapatkan ijin edar obat generik tersebut. Jika obat generik dapat dipasarkan secara efektif, obat tersebut dapat menurunkan harga obat paten yang terbukti lebih mahal dibandingkan versi generiknya. Pasal 135 (b) adalah bagian dari UU Paten Indonesia yang bertujuan untuk meningkatkan ketersediaan dan keterjangkauan produk farmasi yang dibutuhkan oleh masyarakat luas.

\section{a. Evaluasi peraturan bolar provision Indonesia dari perspektif Perjanjian TRIPS}

Bolar provisions adalah salah satu pengecualian terbatas yang diijinkan oleh perjanjian TRIPS terhadap hak-hak eksklusif yang dimiliki oleh pemegang paten. Berdasarkan ketentuan Pasal 30 TRIPS, pengecualian seperti itu tidak dilarang sepanjang tidak bertentangan dengan pemanfaatan paten secara normal dan tidak bertentanga dengan kepentingan yang sah dari pemegang paten. ${ }^{51}$ Penggunaan obat-obatan melalui uji coba dan produksi ini, diperbolehkan hanya untuk kegiatan dan keperluan perolehan ijin edar dan bukan ditujukan untuk kepentingan komersial. Hal ini disebabkan karena aktivitas tersebut masih dalam taraf perlindungan paten. Dengan mentaati ketentuan ini, kegiatan yang tercakup di dalam bolar provisions tidak membahayakan kepentingan yang wajar dari pemegang paten. Oleh karena itu, peraturan bolar provision Indonesia sudah sesuai dengan perjanjian TRIPS.

${ }^{51}$ WHO Policy perspective on Medicines, Equitabel Access to Essential Medicines: A Framework for Collective Action, March 2004, WHO, Geneva, hlm. 3, tersedia di http:/ /whqlibdoc.who.int/hq / 2004/WHO_EDM_2004.4.pdf (last visited 03/06/06) 


\section{b. Kritik dan saran terhadap penyempurnaan peraturan bolar provision di Indonesia berdasarkan perspektif perjanjian TRIPS}

Peraturan mengenai bolar provisions di Indonesia belumlah jelas dan terperinci. Prosedur permohonan ijin edar tidak jelas. Apakah obat-obat yang akan diproduksi versi generiknya melalui bolar provision akan menempuh prosedur permohonan yang sama dengan produksi obatobatan lain di luar bolar provision atau harus menempuh prosedur yang lebih khusus? Jenis-jenis obat apakah yang dibutuhkan oleh pemerintah dan perlu diproduksi versi generiknya melalui bolar provision? Dikarenakan prosedur yang memakan waktu yang lama, apakah ada jalur khusus yang harus ditempuh oleh pemohon produksi obat generik berdasarkan bolar provision? Pemerintah Indonesia perlu mempertimbangkan pertanyaan-pertanyaan tersebut untuk memudahkan pelaksanaan bolar provison yang efektif dan mencapai sasaran di sektor kesehatan masyarakat. Pengaturan yang lebih jelas seperti yang akan dipaparkan berikut ini juga akan meminimalkan kemungkinan timbulnya konflik antar pemerintah Indonesia dengan perusahaan farmasi multinasional:

i) Permohonan bolar provision seharusnya dikontrol oleh pemerintah dengan dasar hukum dan ketentuan yang lebih jelas dan rinci. Peraturan ini termasuk mengenai prosedur untuk mencari ijin edar di Badan POM.

ii) Pemerintah seharusnya juga menyediakan berbagai kebijakan yang berfungsi untuk melindungi kepentingan para pemegang paten dari tindakan penyalahgunaan peraturan bolar provision di Indonesia dengan membatasi pelaksanaan bolar provision hanya pada hal-hal yang bersifat administratif. Jika pelaksanaan bolar provision melebihi dari ketentuan tersebut, pemerintah harus mengatur mengenai sanksi yang akan diberikan baik kepada pihak ketiga maupun kepada para petugas yang terlibat dengan pelaksanaan bolar provision.

iii) Pemerintah seharusnya memutuskan jenis-jenis obat apakah yang sangat diperlukan oleh masyarakat luas dan menajdi prioritas di dalam pelaksanaan bolar provision. Kebijakan ini harus didasarkan kepada kebijakan untuk menyediakan obat yang murah dan terjangkau kepada masyarakat luas. Proses pemilihan obat-obatan yang diperlukan tersebut harus dilakukan secara transparan untuk mencegah penyalahgunaan bolar provision. 


\section{Lisensi Wajib}

Lisensi wajib diatur di dalam UU Paten Indonesia yang berisi ketentuan bahwa otoritas publik (dalam hal ini adalah Ditjen HaKI) dapat mengijinkan pihak ketiga tanpa ijin pemegang paten untuk memproduksi invensi pemegang paten. Pemberian ijin ini dapat dilakukan berdasarkan persyaratan tertentu seperti adanya keadaan yang mendesak di bidang kesehatan masyarakat. Lisensi wajib juga dimaksudkan untuk melindungi kepentingan publik dari dampak negatif perlindungan paten obat. UU Paten Indonesia mengatur lisensi wajib di dalam Pasal 74-87. Lisensi wajib diberikan oleh Direktorat Jenderal Hak Kekayaan Intelektual. ${ }^{52}$

Naomi A. Bass berbendapat bahwa lisensi wajib adalah strategi yang sangat efektif bagi negara-negara berkembang untuk mendapatkan akses obat yang lebih murah dan terjangkau. Dia juga mengungkapkan bahwa berdasarkan sebuah penelitian lisensi wajib dapat menurunkan harga obat sekitar75\%. ${ }^{53}$

\section{a. Apakah peraturan lisensi wajib konsisten dengan perjanjian TRIPS?}

Pasal 31 perjanjian TRIPS mengijinkan anggota WTO untuk menggunakan paten tanpa ijin dari pemegang hak, termasuk pelaksanaan paten oleh pemerintah atau pihak ketiga yang dijinkan oleh pemerintah. ${ }^{54}$ Berdasarkan pasal tersebut, pengunaan paten yang demikian seharusnya diperbolehkan dan dihormati. ${ }^{55}$

Di dalam UU Paten Indonesia peraturan mengenai lisensi wajib memenuhi semua persyaratan yang diperintahkan oleh perjanjian TRIPS, seperti para pemohon lisensi wajib harus memohon kepada pemegang paten untuk mendapatkan lisensi tetapi tidak berhasil (Pasal 76 [1. a.3] UU Paten Indonesia), konsisten dengan Pasal 31 (b) perjanjian TRIPS. Beberapa aspek dari UU Paten tahun 2001 juga sesuai dengan pasal-pasal yang ada di dalam perjanjian TRIPS. Sebagai contoh, Pasal 76, 77, 80, 83, 84 dan 85 yang mengatur mengenai proses pemberian lisensi wajib adalah konsisten dengan Pasal 31 (g) TRIPS.

\footnotetext{
52 Pasal 74 UU No.14 tahun 2001.

${ }^{53}$ Naomi A. Bass, Bass, Naomi A, The Implications of the TRIPS Agreement for Developing Countries: Pharmaceutical Patent Laws in Brazil and South Africa in the 21 Century, 34 George Washington International Law Review 191, 6 (2002).

${ }^{54}$ WHO Policy Perspectives on Medicines, supra note 51, hlm. 3.
} 
Lisensi wajib harus dalam bentuk non-eksklusif (Pasal 79 [a]), lisensi wajib adalah hanya untuk pasar domestik (Pasal 79 [g]) dan pembayaran royalti yang sesuai (Pasal 78 [Ayat.1]) adalah contoh pasal-pasal yang sesuai dengan ketentuan Pasal 31 (d), (f) and (h) perjanjian TRIPS. Ketentuan-ketentuan ini menunjukan bahwa peraturan mengenai lisensi wajib Indonesia sesuai dengan perjanjian TRIPS.

\section{b. Saran perbaikan peraturan lisensi wajib di Indonesia}

Ada beberapa hal dari peraturan lisensi wajib Indonesia yang perlu ditingkatkan.

i) Lisensi wajib Indonesia belum menjelaskan secara detail mengenai dasar hukum pemberian lisensi wajib seperti penyakit yang bersifat epidemik, atau krisis kesehatan (misalnya HIV/AIDS, TBC dan Malaria). Akibatnya, lisensi wajib hanya dibatasi terhadap alasan kepentingan umum serta tidak menjelaskan dengan khusus mengenai kategori kepentingan umum tersebut.

ii) Pasal-pasal lisensi wajib di Indonesia tidak menjelaskan secara rinci mengenai kategori atau jumlah royalti yang seharusnya diberikan kepada para pemegang paten. Jika para pemegang paten menolak jumlah royalti yang akan dibayarkan kepada mereka, UU Paten Indonesia belum menyediakan peraturan mengenai upaya untuk bernegosiasi atau menuntut Ditjen HaKI selaku pemberi ijin pemberian lisensi wajib tersebut.

iii) Seharusnya ada kriteria yang jelas mengenai jumlah pemberian royalti yang ditawarkan kepada para pemegang paten. Prosedur untuk menghitung jumlah royalti tersebut haruslah adil dan tidak bersifat diskriminatif bagi para pemegang paten, yang diatur di dalam uu paten maupun peraturan pelaksananya.

\section{Pelaksanaan Paten oleh Pemerintah}

Pelaksanaan paten oleh pemerintah adalah sebuah keputusan yang mengijinkan pemerintah untuk memproduksi paten tertentu yang dimiliki oleh pemegang paten untuk keperluan pertahanan dan keamanan negara dan untuk situasi mendesak di bidang kesehatan masyarakat untuk kepentingan masyarakat umum. ${ }^{56}$ Government use diatur di dalam Bab

\footnotetext{
${ }^{56}$ Pasal 99 UU Paten Indonesia.
} 
VII UU Paten Indonesia mulai Pasal 99 sampai dengan Pasal 103. Penjelasan Pasal 99 menerangkan bahwa contoh-contoh invensi yang sangat penting bagi pertahanan dan keamanan negara adalah bahanbahan peledak, senjata dan amunisi. Sedangkan contoh-contoh kepentingan umum yang mendesak diantaranya adalah kebijakan untuk mengatasi penyakit endemik, dan kebutuhan mendesak akan pestisida tertentu dikarenakan bencana gagal panen.

\section{a. Evaluasi terhadap peraturan government use di dalam UU Paten Indonesia}

Seperti halnya konsep lisensi wajib, government use dibenarkan oleh Pasal 31 Perjanjian TRIPS. Pasal tersebut mengijinkan anggota WTO untuk menggunakan paten tanpa ijin dari pemegang paten berdasarkan kondisikondisi tertentu, misalnya perlindungan terhadap kepentingan umum. TRIPS juga mensyaratkan bahwa bentuk permohonan terhadap government use harus bersifat lisensi non eksklusif, adanya ganti kerugian yang layak (royalti) kepada pemegang paten serta adanya badan atau otoritas yang meninjau ulang pelaksanaan melalui sebuah mekanisme hukum yang independen.

Government use berbeda dengan lisensi wajib karena government use tidak mensyaratkan adanya usaha awal untuk memohon pelaksanaan paten seseorang seperti halnya yang disyaratkan terhadap lisensi wajib. Syarat tersebut tidak dimasukkan ke dalam government use oleh perjanjian TRIPS karena government use hanya berhubungan dengan keadaan darurat dan mendesak. Meskipun demikian, pemerintah perlu memberitahukan rencana untuk melaksanakan government use kepada pemegang paten.

Pasal 99-101 UU Paten Indonesia memenuhi semua persyaratan yang ditetapkan oleh perjanjian TRIPS. Sebagai contoh, Pasal 101 mewajibkan pemerintah untuk memberitahukan rencana pelaksanaan government use kepada pemegang paten. Pasal 101 ayat 2 mengatur ganti kerugian kepada pemegang paten seperti halnya diatur dalam Pasal 31 TRIPS. Pasal 102 ayat 2 UU Paten Indonesia mengijinkan pemegang paten untuk tidak menyetujui pemberian jumlah royalti yang ditawarkan oleh pemerintah. Para pemegang paten yang tidak puas dengan jumlah tersebut dapat mengajukan keberatannya kepada Pengadilan Niaga. Ketentuan ini sejalan dengan Pasal 31 b (i) Perjanjian TRIPS yang mengatur mengenai adanya 
lembaga yang akan meninjau berbagai kebijakan di seputar pelaksanaan government use dan bersifat independen. Berdasarkan fakta-fakta tersebut, peraturan government use Indonesia sejalan dengan ketentuan yang terdapat di dalam perjanjian TRIPS.

\section{b. Kritik dan Saran terhadap peraturan government use di Indonesia berdasarkan perspektif TRIPS}

Paparan berikut ini adalah beberapa hal yang perlu dilakukan oleh pemerintah untuk memperbaiki peraturan government use di Indonesia. i) Definisi ganti kerugian yang mencukupi seperti diatur di dalam Pasal 101 ayat 2 UU Paten Indonesia belumlah memadai. Pemerintah seharusnya menyediakan prosedur negosiasi atau banding yang lebih jelas terhadap keberatan yang diajukan oleh pemegang paten berkaitan dengan royalti yang diusulkan.

ii) Pasal 102 Ayat 2 mengijinkan pemegang paten untuk mengajukan keberatannya dengan jumlah royalti yang diusulkan oleh pemerintah dan membawa permasalahan tersebut ke Pengadilan Niaga. Pasal tersebut juga harus berisikan ketentuan mengenai banding atau kasasi apabila pemegang paten kalah di Pengadilan Niaga.

Sebagai alternatif, jika pemerintah memutuskan bahwa tidak ada banding atau kasasi terhadap keputusan Pengadilan Niaga berkenaan dengan keberatan pemegang paten terhadap jumlah royalti yang tidak sesuai, pemerintah seharusnya menyatakan hal tersebut secara jelas di dalam UU Paten Indonesia.

Tabel berikut ini, akan menyimpulkan paparan mengenai pasal-pasal pelindung TRIPS di dalam UU Paten Indonesia. Tabel ini juga akan menyediakan rangkuman terhadap saran-saran untuk menyempurnakan pasal-pasal tersebut. 
Tabel 1-1.

Pasal Pelindung TRIPS dan Saran Penyempurnaannya

\begin{tabular}{|c|c|c|c|}
\hline No. & Safeguards & Permasalahan & Saran Penyempurnaan \\
\hline 1. & $\begin{array}{l}\text { Impor } \\
\text { Paralel }\end{array}$ & $\begin{array}{l}\text { - Peraturan tidak jelas } \\
\text { dan rinci tentang } \\
\text { pihak-pihak yang } \\
\text { bertanggung jawab } \\
\text { terhadap } \\
\text { pelaksanaannya } \\
\text { - Prosedur } \\
\text { pelaksanaannya tidak } \\
\text { jelas } \\
\text { - Pengetahuan para } \\
\text { Staf instansi terkait } \\
\text { tidak memadai. } \\
\text { - Daftar target obat } \\
\text { yang dibutuhkan } \\
\text { belum tersedia. }\end{array}$ & $\begin{array}{l}\text { - Meninjau ulang } \\
\text { lembaga-lembaga yang } \\
\text { bertanggung jawab } \\
\text { terhadap pelaksanaan } \\
\text { impor paralel. } \\
\text { - Menyediakan pelatihan } \\
\text { dan pengawasan } \\
\text { terhadap para staff } \\
\text { terkait } \\
\text { - Menyediakan } \\
\text { penjelasan yang } \\
\text { spesifik terhadap impor } \\
\text { paralel }\end{array}$ \\
\hline 2. & $\begin{array}{l}\text { Bolar } \\
\text { Provision }\end{array}$ & $\begin{array}{l}\text { - Penjelasan kegiatan } \\
\text { yang harus dilakukan } \\
\text { kurang jelas. } \\
\text { - Pembuatan daftar } \\
\text { obat generik yang } \\
\text { diprioritaskan belum } \\
\text { tersedia. }\end{array}$ & $\begin{array}{l}\text { - Menyediakan pp } \\
\text { tentang pelaksanaan } \\
\text { bolar provision } \\
\text { - Menyediakan daftar } \\
\text { obat prioritas untuk } \\
\text { bolar provision. }\end{array}$ \\
\hline 3. & $\begin{array}{l}\text { Lisensi } \\
\text { Wajib }\end{array}$ & $\begin{array}{l}\text { - Dasar hukum } \\
\text { pemberian lisensi } \\
\text { wajib belum diperjelas } \\
\text { - Pasal-pasal yang } \\
\text { mengatur jumlah } \\
\text { royalti belum tersedia }\end{array}$ & $\begin{array}{l}\text { - Membuat kategori atau } \\
\text { jumlah royalti yang } \\
\text { layak. Menyediakan } \\
\text { kriteria pemberian } \\
\text { ganti kerugian atau } \\
\text { royalti }\end{array}$ \\
\hline 4. & $\begin{array}{l}\text { Government } \\
\text { Use }\end{array}$ & $\begin{array}{l}\text { - Definisi ganti kerugian } \\
\text { tidak mencukupi } \\
\text { - Prosedur banding dan } \\
\text { kasasi yang belum } \\
\text { jelas }\end{array}$ & $\begin{array}{l}\text { - Menyediakan prosedur } \\
\text { negosiasi atau banding } \\
\text { yang lebih jelas kepada } \\
\text { pemegang paten. } \\
\text { - Menyediakan } \\
\text { ketentaun terhadap } \\
\text { banding dan kasasi jika } \\
\text { pemedang paten kalah } \\
\text { di pengadilan Niaga }\end{array}$ \\
\hline
\end{tabular}




\section{Penutup}

Berdasar uraian di atas dapat disimpulkan bahwa, perlindungan paten obat menciptakan situasi yang dilematis bagi pemerintah Indonesia dimana perlindungan tersebut menciptakan konflik antara kebijakan pembangunan domestik dengan standard-standard internasional. Meskipun demikian, pemerintah tidak memiliki pilihan tetapi harus menyesuaikan peraturan paten nasional dengan perjanjian TRIPS. Untuk itu, pemerintah Indonesia harus memaksimalkan kebijakan-kebijakan yang bersumber dari pasal-pasal pelindung TRIPS untuk mengantisipasi dampak-dampak negatif yang timbul dari perlindungan paten obat di sektor kesehatan masyarakat, seperti impor paralel, bolar provision, lisensi wajib dan government use.

Oleh karena itu, pasal-pasal pelindung TRIPS seharusnya menjadi prioritas di dalam agenda pembangunan Indonesia. Dengan demikian, pasal-pasal pelindung dapat dilaksanakan dengan efektif dan dapat diandalkan untuk mengatasi dampak negatif dari perlindungan paten. Yang terpenting, pemerintah harus memastikan bahwa semua kebijakan yang dilakukan untuk memastikan akses obat essential yang lebih baik bagi masyarakat luas sejalan dengan ketentuan yang terdapat di dalam perjanjian TRIPS.

\section{Daftar Pustaka}

Achadiat, Chrisdiono M., Perlukah MKEK "Bersidang" (Juga)? Kompas, 26 July 2002, tersedia di http://www.kompas.com/kompas-cetak/ 0207/26/iptek/perl37 .htm

ADB, Supporting Health Systems in Indonesia, CGI Health Working Group Meeting, 10 Desember 2003, Jakarta, tersedia di http:// Inweb18.Worldbank.org / eap/eap.nsf/Attachments/CGI-1203ADB-health/\$File/ADB-Health.pdf (last visited 03/06/06)

Azwar, Azrul, Beberapa Catatan Tentang UU Perlindungan Konsumen dan Dampaknya Terhadap Pelayanan Kesehatan, tersedia di http:// www.idionline .org/ arsip/jurnal/beberapa_catatan_tentang_ UU_Perlindungan_Konsumen.pdf

Bass, Naomi A, The Implications of the TRIPS Agreement for Developing Countries: Pharmaceutical Patent Laws in Brazil and South Africa in the $21^{\text {st }}$ Century, 34 George Washington International Law Review 
191 (2002)

Buletin Desentralisasi Kesehatan, Desentralisasi Kesehatan dan Perubahan Peran Pemerintah dalam Pembiayaan Volume II/02/2004, tersedia di http://www.desentralisasi-kesehatan.net

Center for Health Service and Management, Gadjah Mada University, Laporan Seminar Nasional 4 Tahun Desentralisasi Kesehatan di Indonesia (A National Seminar Report of the Four Year Health Decentralization in Indonesia), Hotel Marannu, Makassar, 7-9 June 2005, tersedia di http:/ / www.desentralisasi-kesehatan.info/doc/LapSemNas4thn DesKes.pdf (last visited 09/14/06)

Depkes RI , 1978, Sejarah Kesehatan Nasional Indonesia Jilid 1 (vol. 1), Jakarta, Depkes

1980, Sejarah Kesehatan Nasional Indonesia Jilid 2 (vol. 2), Jakarta, Depkes - Profil Kesehatan Indonesia 2001 (The Indonesian Health Profile 2001), tersedia di http://www.depkes.go.id/downloads/Narasi2001.pdf Kebijakan Obat Nasional (KONAS) 2005 Jakarta, Depkes RI/ The Department of Health of The Republic of Indonesia, tersedia di http:/ / www.depkes.go.id/downloads / konas. pdf

Embassy of India in Jakarta, Indonesia, The Market for Pharmaceutical Products and Materials in Indonesia, prepared by PT Data Consult, tersedia di http: / /www.embassyofindiajakarta. org/Pharmaceutical_mkt_ survey.pdf

Karnadihardja, Warko and Kiki Lukman, Antisipasi Terhadap Krisis Ketenagaan Dokter Spesialis in Indonesia Menjelang Tahun 2003 (Anticipation for the Critical Condition of Specialist Doctors' Availability in Indonesia in 2003), tersedia di http://dokter.indo.net.id/krisis.doc

Kenneth M. Chomitz et al, What Do Doctors Want? Developing Incentives for Doctors to Serve in Indonesia's Rural and Remote Areas, tersedia di http: //www.worldbank.org/html/dec/Publications / Workpapers/WPS1800 series/ wps1888/wps1888.pdf

Lindsey, Tim et al (eds), 2002, Hak Kekayaan Intelektual Suatu Pengantar, Bandung, Penerbit Alumni

Myrttinen, Henri, Indonesian Economic Policy at Crossroads?, tersedia di http:/ / www.kepa.fi/international/English/information/newsletter $/ 2003 / 3472$

Program Pasca Sarjana [Postgraduate Program] Universitas Indonesia, 
Sejarah Pasca Sarjana UI tersedia di http:/ / pps.ui.ac.id/sejarah.htm). PUSDIKNAKES (1), Terbuka Lebar, Peluang Kerja Perawat di Amerika, Arab dan Eropa, tersedia di http://www.pusdiknakes.or.id/news/ ragam.php3?id=10

(2), Perawat, Dokter Filipina Berbondong-bondong ke Luar Negeri, tersedia di http://www.pusdiknakes.or.id/news/

(3), Gaji Dokter Indonesia di Saudi Arabia Rp. $10 \mathrm{Juta}$, tersedia di http:// www.pusdiknakes .or.id/news/ utama.php3?id=14

Suara Merdeka, Majelis Kode Etik Bukan Untuk Membela Dokter, tersedia di http:/ / www.suaramerdeka.com/harian/0110/06/kot10.htm (Oktober, 62001)

Thabrany, Hasbullah, et al, Social Health Insurance in Indonesia: Current Status and the Plan for National Health Insurance (Annex 3), presented in Social Health Insurance Workshop, WHO SEARO, New Delhi, March 13-15, 2003, tersedia di http://w3.whosea.org/LinkFiles/ Social_Health_Insurance_an3.pdf (last visited 03/06/06)

UGM Website, Sejarah UGM [The History of the University of Gadjah Mada], tersedia di http:/ / www.ugm.ac.id/content.php?page=0\& display=2)

UNDP, Memerangi HIV/AIDS, Malaria and Penyakit Menular (Laporan Perkembangan Pencapaian Tujuan Pembangunan Millenium Indonesia), tersedia di http://www.undp.or.id/ pubs/imdg2004/BI/ IndonesiaMDG_BI_Goal6.pdf

Wikipedia, Economy of Indonesia, tersedia di http://en.wikipedia.org/wiki/ Economy_of_Indonesia

Wirawan, Kasus Malpraktik Antara Kehormatan Profesi Dan Kepastian Hukum Teropong, Suplemen Pikiran Rakyat, 4 October 2004, tersedia di http: //www.pikiran-rakyat.com/cetak/1004/04/teropong/konsul_ hukum .htm

WHO, Macroeconomics and Health - Indonesia Country Profile, tersedia di http: //www.who.int/macrohealth/action/en/rep04_indonesia.pdf (last visited 03/06/06)

, State of the World's Vaccines and Immunization, Geneva, WHO, tersedia di //www.unicef.org/publications/files/pub_sowvi_en. pdf (2002)

WHO Policy perspective on Medicines, Equitabel Access to Essential Medicines: A Framework for Collective Action, March 2004, WHO, Geneva, tersedia di http://whqlibdoc.who.int/hq/2004/WHO_ EDM_ 2004.4.pdf (last visited 03/06/06) 